\title{
The interpretation of tooth wear - literature review
}

\author{
Soo-Jeong Hwang ${ }^{1}$, Min-Seock Seo ${ }^{2 *}$ \\ 'Department of Dental Hygiene, College of Medical Science, Konyang University, Daejeon, Republic of Korea \\ ${ }^{2}$ Department of Conservative Dentistry, Wonkwang University Daejeon Dental Hospital, Daejeon, Republic of Korea
}

Tooth wear is a multifactorial condition, leading to the loss of dental hard tissues. While for many years, tooth wear was a condition of little interest in daily clinical practice, nowadays this is changed. Tooth wear is becoming increasingly significant in maintaining the long-term health of the dentition. This becomes especially important when the dentition is kept relatively intact in the contemporary ageing population, and edentulism is decreasing. There is also evidence that the prevalence of tooth wear is growing. It is a natural consequence of the unidirectionality of tooth wear that it is frequently used as a means of individual age estimation. Tooth wear was very serious in ancient populations up to the medieval period. Tooth wear is thus studied in a wide variety of areas. The purpose of this paper is to summarize and analyze the many issues surrounding tooth wear through recent studies in various fields and to search for future research direction. (J Dent Rehabil Appl Sci 2018;34(3):137-46)

Key words: abrasion; age estimation; attrition; erosion; tooth wear

\begin{abstract}
서론
치아 마모는 노화의 자연스러운 과정이다. 사람이 살 아가면서 치아 조직의 많은 부분이 상실된다. 이것은 마 모와 파절에 기인한다. 치아 마모는 상아질 과민증, 치수 침범, 비심미적 외관 그리고 치아 경조직 상실 등으로 치 아 상태에 많은 영향을 끼친다. ${ }^{1}$

치아 마모는 치과 영역에서 가장 모호하게 쓰이는 용 어 중 하나이다. 사용하는 사람들에 따라 그 정의가 달라 지기 때문에 구체적인 내용으로 들어가기 전에 치아 마 모라는 용어의 정리가 필요하다. 치아의 경조직이 상실 되는 현상은 원인에 따라 erosion, abrasion, 그리고 attrition으로 나뉜다. ${ }^{2}$ 어떤 연구자는 치아 마모라는 말을 사용할 때 erosion 보다 abrasion 이나 attrition을 더 염 두에 두기도 한다. 치아 마모라는 용어가 널리 사용됨에 도 불구하고 치아 마모의 종류에 대한 임상적 형태와 해

*Correspondence to: Min-Seock Seo

Associate Professor, Department of Conservative Dentistry, Wonkang University Daejeon Dental Hospital, 77 Dunsan-ro, Seo-gu, Daejeon, 35233, Republic of Korea Tel: +82-42-366-1143, Fax: +82-42-366-1115, E-mail: profee@wku.ac.kr Received: February 27, 2018/Last Revision: April 5, 2018/Accepted: May 11,
\end{abstract}

석은 임상가들 사이에서 매우 다양하다. ${ }^{3}$ 엄밀히 말해서, attrition은 치아 대 치아의 접촉으로 인한 기능과 이상 기 능(이갈이 등)으로 인해 내적으로 기계적인 마모가 생기 는 것을 말한다. ${ }^{3} \mathrm{Abrasion}$ 은 기능과 이상기능 외의 결과 로 외적으로 기계적인 마모가 생기는 것을 말한다. Erosion은 우식과 상관없는 내적 또는 외적 산으로 인해 화 학적으로 치아가 마모되는 것을 말한다. ${ }^{4.5}$ 개개의 마모 기전은 따로따로 이루어지지 않고 다른 것과 같이 관계 하여 일어난다. 다시 말해서, 모든 저작 행위에서는 대합 되는 치아로 인해 attrition이 발생한다. 또한 그 사이를 매개하는 음식물로 인한 abrasion이 일어나고 그 음식에 서 생기는 산에 의한 erosion도 일어나게 되기 때문에 이 들을 세세하게 구분하는 것은 사실상 불가능하다. 특히 erosion의 역할이 전통적으로는 많이 조명되지 않았지만 최근 다원성의 치아 마모 과정에서 erosion이 차지하는 비중이 갈수록 증가하고 있다. ${ }^{6}$ 본 논문에서는 치아 마모

Copyright (C) 2018 The Korean Academy of Stomatognathic Function and Occlusion. (c) It is identical to Creative Commons Non-Commercial License. 
를 이 세 가지 모두를 아우르는 용어로 사용하기로 한다. 본 논문에서는 치아 마모를 세부적인 항목으로 구분하지 않고 큰 개념으로 보고 최근 연구들을 중심으로 치아 마 모가 의미하는 의미에 대해 살펴보고자 한다.

\section{문헌고찰}

\section{치아 마모는 증가하고 있는가}

오랫동안 임상가들은 치아 마모에 별다른 관심을 기울 이지 않았다. 하지만 최근 들어 변화가 생기고 있다. 치아 마모는 치아를 오랫동안 건강하게 유지시키는 관점에서 갈수록 그 중요성이 높아지고 있다. 현대 노인 인구에서 과거보다 더 오랜 기간 치아들이 유지되고 있기 때문에 치아 마모가 중요할 수 밖에 없다.

치아 마모의 중요성이 커지는 또 다른 이유는 빈도이 다. 다소의 논쟁이 있지만 치아 마모의 빈도가 이전보다 높아지고 있다는 증거들이 보고되고 있다. ${ }^{7}$ 원래, 치아 마 모는 과거의 인류보다 현대인에게서 급격히 감소한 것으 로 밝혀졌다. Davies와 Pedersen ${ }^{8}$ 은 도시화된 에스키모 인들과 달리 전통적인 방식으로 살아가는 에스키모 인 들의 영구치와 유치 모두에서 매우 높은 치아 마모를 보 였다고 하였다. 또한, 북미 원주민과 그리스 산악족 같이 고립되어 전통적인 방식으로 사는 집단에서 매우 광범위 한 치아 마모가 보고되었다. ${ }^{9,10}$

극도로 도시화된 현대 인류에서 치아 마모는 계속 감 소하고 있는 것으로 여겨졌었다. 하지만 최근 들어서 치 아 마모가 다시 증가하고 있다는 연구들이 보고되고 있 다. 영국의 한 연구에서는 1998년과 2009년 치아 마모를 조사하여 이를 비교하였다. 그 결과 전치부 치아 마모의 빈도가 1998년 66\%에서 2009년 77\%로 증가하였다. 또 한 심각한 마모의 빈도는 감소하였지만 젊은 사람들(16 - 34세)에서 중등도의 마모가 증가하고 있었다. ${ }^{11}$ 2013년 Wetselaar는 네덜란드에서 치아 마모의 빈도를 조사여 이 것을 같은 방식으로 조사하였던 2007년 자료와 비교 하였다. 그는 6년 사이에 치아 마모가 유의미하게 증가하 였다고 분석하였다. ${ }^{12}$ 현대 사회에서 감소하던 치아 마모 가 최근 들어 증가하게 되었다는 것은 여러 면에서 치아 마모를 더 잘 살펴볼 필요성을 말해준다.

\section{치아마모의 빈도와 그에 관련된 요소}

치아 마모의 빈도는 어떤 기준을 적용하는 가에 따라 연구마다 차이가 있기 때문에 상대적인 방법으로 파악한 다. Hugoson 등 $^{13}$ 에 따르면 치아 마모의 빈도는 20세 때 는 $13.6 \%$ 였지만 50 세에서는 $24.1 \%$ 로 증가한다고 하였 다. Spijker 등 ${ }^{14}$ 에 의하면 심한 치아 마모를 보이는 성인 의 빈도는 20 세 때는 $3 \%$ 이고 70 세에는 $17 \%$ 까지 상승 한다고 하였다. 결론적으로 나이에 따라서 마모가 증가 하는 경향이 뚜렷하였다. 중국의 우한 지역에서 2014년 720 명을 대상으로 시행한 연구에 의하면 치아 마모의 빈 도는 35-49세 구간에서 67.5\%였고 50세 이상에서 100\% 로 보고하였다 ${ }^{15}$. 같은 연구에서 치아 마모와의 관련 요 소를 분석한 결과, 산성 식음료의 소비가 높은 것, 사회경제적 지위가 낮은 것, 그리고 한 쪽으로 저작하는 것이 치아 마모와 밀접한 관련이 있는 것으로 나타났다.

치아 마모는 이갈이(bruxism)와 연관하여 설명하기도 한다. 문헌들은 이갈이의 빈도를 성인에서는 $8-31.4 \%$ 그리고 어린이에서는 $3.5-40.6 \%$ 로 넓게 보고하였다. ${ }^{16,17}$ 253 명의 20 대 대학생을 대상으로 한 Soares 등 ${ }^{18}$ 의 연구 에 의하면 $31.6 \%$ 가 이갈이가 있고 $5.3 \%$ 의 치아에서 어 느 정도의 면마모(facet wear)를 보였다. 스트레스가 있 는 학생들은 그렇지 않은 사람보다 3.10 배 더 높게 이갈 이가 있었다. 위의 연구들을 종합해 보면 스트레스를 많 이 받는 사람일수록 이갈이가 더 많이 나타났고 결과적 으로 치아 마모가 더 많이 나타났다.

이와 관련하여 치아 마모가 정서적인 부분과 관련이 높다고 말하는 연구들이 있다. Brignardello ${ }^{19}$ 은 심한 치 아 마모가 있는 사람들 중에서 정서적 불안정을 느끼는 경우가 많았고 불안감을 느끼는 경우도 더 높았다고 하 였다. 그들은 정신적인 측면과 치아 마모 사이에 유의미 한 상관관계를 보고하였다. 더 나아가 치아 마모를 정신 적인 상태와 장애를 진단하는 도구로 사용하려는 시도들 도 있었다. 영국, 독일 그리고 이탈리아의 13057 명을 대 상으로 한 횡단면 연구에서 불안, 스트레스, 흡연, 그리 고 과음주 습관을 가지고 있는 참가자들의 $8.2 \%$ 는 적어 도 1 주일에 한번 정도의 이갈이 습관이 있었다. ${ }^{20} 30$ - 55 세 사이의 1784 명을 대상으로 한 다른 연구에서는 이갈 이와 스트레스 경험을 설문으로 조사하였고 둘 사이에는 유의미한 상관관계가 있었다. ${ }^{21}$ 상급자나 동료에게서 생 기는 높은 정신적 스트레스와 우울증이 이갈이와 유의미 한 상관관계가 있음이 2680명을 대상으로 한 연구에서 
도 나타났다. ${ }^{22}$ 이런 결과들을 종합하면 치아 마모가 정 서적 안정감, 스트레스, 우울증 등과 유의미한 관계가 있 다고 할 수 있다.

치아 마모와 삶의 만족도를 조사한 연구도 있었다. AlOmiri 등 ${ }^{23}$ 은 마모도 높은 사람들 집단과 같은 수의 대조 군 집단을 조사하였다. 남녀 모두 마모도가 높은 군에서 자신의 외모에 대해 만족하지 못한다는 비율이 높았다. 마모도가 높은 군에서 약 $36 \%$ 는 자신의 치아에 만족하 지 못하였고 이는 정상군의 $9 \%$ 에 비해 매우 높은 수치였 다. 치아 마모도가 높은 사람들은 그렇지 않은 사람들에 비해 다른 수준의 삶의 만족도를 가지고 있다고 결론지 었다. 또한 치아 마모도가 높으면 외모, 통증, 구강 건강, 저작과 전반적인 치열에서 높은 수준의 불만족도를 보였 다. 둘 사이의 선후관계가 어떻게 이루어지는 지까지는 밝혀지지 않았지만 치아 마모와 삶의 만족도에 어떤 관 계가 있을 수 있다는 가능성을 볼 수 있다.

\section{연령감정에서 치아 마모의 의미}

치아 마모에 대한 양과 속도를 조사한 연구들이 있 다. 한 연구에 따르면 상악 중절치는 11 세에 최대의 길이 로 70세에 이르면 길이가 $1.01 \mathrm{~mm}$ 정도 감소하였다. 유 사하게 하악 중절치는 70 세에 이르면 11세에 비해 1.46 $\mathrm{mm}$ 정도 감소하였다. 전반적으로 10 년간 상악 중절치 길이는 $0.17 \mathrm{~mm}$ 마모되고 하악 중절치의 길이는 0.25 $\mathrm{mm}$ 감소하였다. ${ }^{24}$ 치아의 가장 바깥면을 형성하는 법랑 질은 한번 변화가 상기면 다시 리모델링 될 수 없기 때문 에 이런 점을 이용하여 연령을 감정하려는 시도들은 오 래 전부터 있었다.

성인의 나이를 알아내기 위해 치아를 사용하는 연령 감정법은 1950 년 구스타프슨에 의해 처음 개발되었다. 1971년 존슨은 구스타프슨의 방법을 개선하였고 이 방 법은 그 이후로 법의학자들에게 널리 쓰이게 되었다. ${ }^{25}$ 치 아 마모를 이용한 연령 감정법은 상대적으로 빠르고 비 파괴적으로 할 수 있기 때문에 시간을 다투는 조사에서 유용하게 사용되어 왔다. 하지만 사회가 빠르게 현대화 되고 도시화되면서 치아 마모로 연령을 올바르게 감정할 수 있는지에 대한 의문들이 제기되었다.

현대의 부드러운 음식들은 예전만큼 치아를 마모 시키 지 못한다. 이 때문에 치아 마모로 연령감정을 하는 것은 적어도 현대 서구인들에게는 불확실한 것으로 여겨진다. 또한 치아 마모의 정도는 그가 속한 사회 전반적인 문화
에 따라 달라진다. 아마존의 고립된 원주민 집단에서의 치아마모를 평가하여 아마존의 하류의 도시지역 인구들 과 비교를 한 연구에 따르면 고립된 지역의 원주민 집단 에서는 $70-86 \%$ 의 경우 치아 마모로 인한 연령 추정이 정확도를 보였지만 도시지역의 집단에서는 그 정확도가 $12 \%$ 에 불과하였다. 치아 마모는 도시화된 인구의 연령 을 추정하는데 적합하지 않다고 하였다. ${ }^{26}$

$\mathrm{Kim}$ 등 $^{27}$ 은 2000 년 한국인의 자료를 토대로 연령 감정 법을 개발하였다. 이 방법은 13세에서 79세까지의 현대 한국인 중 부정교합이 없고 해당 부위 수술을 받지 않았 고 보철치료를 받지 않은 383명의 샘플을 이용하여 만들 어졌다. 그 이후 Yun 등 ${ }^{28}$ 은 2007년 이 방법을 수정하였 다. 이 방법들은 같은 연구자들에 의한 정확도 연구에서 분석 대상의 $60 \%$ 가 5 년 내로 감정되었고 대상이 45 세 기 준으로 구분이 된다면 그 정확성은 $80 \%$ 를 넘는다고 하 였다. ${ }^{29}$ 이 정도의 정확성은 그 유래를 찾지 못할 정도로 매우 높은 것으로 이 방법이 안정적으로 같은 정확도를 보이는 지는 아직 다른 선진국에서 증명되지 못하였다.

이런 연령 감정법의 가장 큰 한계점은 추정되는 연령의 범위가 넓다는 점이다. 정확한 연령이 필요한 조사에서 이 부분은 특히 문제가 될 수 있다. 그렇기 때문에 45세 전 후로 추정 연령의 범위를 구분하여 분석함으로써 좀 더 높은 정확성을 추구하려고 하는 시도가 이루어지고 있다. 윤 등의 방법을 현대의 미국인들에게 적용하여 연 령 측정한 연구에서 치아 마모로 추정된 연령이 실제 연 령의 상하 10 년 안에 드는 정확도가 $39 \%$ 에 불과한 것으 로 나타났다. 하지만 50세 이하와 이상으로 구분하여 분 석한 결과 정확도가 $60 \%$ 로 증가하였다. ${ }^{30}$

Al-Dlaigan 등 ${ }^{30}$ 의 연구에 의하면 영국의 14 세 아이들 중에서 사회경제적면에서 상대적으로 낮은 배경의 아이 들은 높은 배경의 아이들보다 더 높은 erosion을 보인다 고 하였다. 하지만 다른 연구에서 4 세 어린이의 경우 높 은 사회경제적 배경의 아이들에게서 erosion이 더 많이 일어났다. ${ }^{31}$ 저자들은 연령대에 따른 차이는 탄산음료 소 비와 식생활, 구강 위생 그리고 위식도 역류 반사에 영향 을 받는다고 하였다. 이와 같이 여러 가지 변수들이 존재 하기 때문에 일반적인 치아 마모도로 연령을 측정하는 것은 한계가 있을 수 밖에 없다.

요약하지만 치아 마모를 이용한 연령 감정법이 정확하지 못하고 그 추정 나이 범위도 너무 넓다고 주장하는 사람들 이 늘어나고 있는 추세이다. 그래서 성인 유골의 연령 감정 은 고고학이나 법의학에서 오래된 논쟁거리로 남아있다. 


\section{고고학에서 치아 마모의 의미}

치아가 고고학 분야에서 매우 중요한 역할을 할 수 있 는 이유는 두 가지가 있다. 첫째로 치아는 사후 손상의 과정에서 매우 저항적이어서 사체의 보관 상태에 관계없 이 매우 긴 시간 동안 원래의 형태를 유지할 수 있다. 둘 째로 과거에는 수복이나 수술과 같은 치과 치료가 없었 고 치아 우식이 고대에는 매우 드물었기 때문에 원래적 인 형태로 연구할 수 있다. ${ }^{32}$ 치의학과 달리 고고학에서는 erosion이나 attrition보다는 치아 마모(wear)라는 말을 전통적으로 선호하였다. 이들을 정확히 구분하려면 여러 정보들이 필요하고 임상 검사, 진단 기구 사용, 환자와의 대화 그리고 생물학적 지식이 필요하다. 고고학적으로 이런 과정이 불가능하기 때문에 작은 단위 용어 보다는 더 넓은 개념의 치아 마모라는 용어를 선호한다. 하지만 중세의 유골에서는 교합면이 움푹 파여지는 형태의 교합 면 마모가 많이 발견되는 대신 현대인에게 흔한 치경부 abrasion이 거의 발견되지 않는 세부적 차이는 분명히 존 재한다. ${ }^{33}$

고고학에서 치아 마모를 말할 때 식물석(phytolith)은 치아 마모의 가장 중요한 요소로 여겨진다. 식물 재료, 식 물석, 아주 작은 돌과 치아는 고고학에서 말하는 치아 마 모의 거의 모든 요소라 할 수 있다. 식물석은 법랑질을 없 애기 보다는 소성 변형을 시킨다. 하지만 최근의 연구에 따르면 식물석은 실제로 법랑질에 충격을 준다고 한다. 법랑질보다 연한 입자들은 소성 변형이 아니라 법랑질에 조직 손상으로 미세한 고랑(groove)을 형성한다. ${ }^{34}$ 최근 들어서 이와 관련한 작업이 보고되고 있지만 음식의 구 성에 따른 그에 상응하는 마모율의 현저한 차이는 뚜렷 이 증명되지 않았다.

법랑질에 긁힘(scratch)이 높게 나타나는 것은 마모성 식습관과 관련된 것이다. 긁힘은 입자가 법랑질 표면에 닿고 저작되면서 나타난다. 소와(pit)가 생기는 것은 단 단한 음식(씨앗과 nut)을 소비하는 것과 관련된다. 이탈 리아의 청동기 시대의 유골을 분석한 연구에서 긴 긁힘이 주로 발견되고 소와가 잘 나타나지 않는다는 것을 발견 하였는데 그것은 마모성 음식이 저작과정에서 교합면 쪽 으로 압박하는 힘이 작용하기 보다는 교합면과 평행하 게 힘이 작용하였다는 것을 의미한다. 이를 토대로 이 시 기에는 주로 채소가 많은 식생활이 이루어졌다고 분석하 였다. ${ }^{35}$ 이처럼 최근에는 단순한 마모의 양보다는 세세한 마모의 흔적을 가지고 분석을 하기 때문에 해상도 높은
$3 \mathrm{D}$ 스캐너를 이용하여 현미경적 분석을 하게 된다.

마모의 방향은 아직 많이 연구되지는 않았다. Bra$\operatorname{bant}^{36}$ 에 의하면 중세시대에서 가장 흔하게 나타나는 치 아 마모 방향은 나선형이다. 그는 이런 마모 방향은 잘 갈리지 않는 거친 음식을 느리게 저작하는' 결과라고 하 였다. 유럽의 빌라누 지방의 중세시대 유골에서 가장 많 이 발견되는 방향은 남자에서는 사선 방향이었고 여자에 서는 수평 방향이었다. ${ }^{37}$

시대와 장소를 초월하여 보편적으로 여자보다 남자에 서 치아 마모도가 높게 관찰되었다. 16세기와 17세기 사 이의 크로아티아 인구 집단에서 Slaus 등 ${ }^{38}$ 은 남성이 여성 보다 교합면 마모가 유의미하게 높았다고 하였다. 이탈 리아의 청동기 시대의 유골 연구에 따르면 역시 남성이 여성보다 높은 수준의 마모를 보인다고 하였다. 이런 성 별의 차이는 고기 소비량과 관련이 있다. 주로 고기를 먹 으면서 잔뼈를 씹게 되는데 그러한 외상에 노출되는 것 이 높은 치아 마모도와 연관된다..$^{39}$

$\operatorname{Anderson}^{40}$ 은 1965년 최초로 치아 마모와 식생활의 상 관관계에 관한 연구를 발표하였다. 그는 농경사회 이전 의 멕시코 원주민에 대해 조사하여 농경 사회 집단에서 는 나타나지 않는 분명한 치아 마모 양상을 발견하였다. 그는 치아 마모와 마모 양상은 인구 집단의 기초생활과 식생활의 재구성하는 데 단초가 될 수 있다고 하였다. 치 아 마모도는 여러 가지 변수에 좌우되는데 음식의 밀도 와 질감, 음식을 조리하는 방식, 문화적 관습, 나이 또는 성별들이 바로 그 변수들이다. 예를 들어 에스키모 집단 의 유골 연구에 의하면 말린 생선을 먹는 것은 높은 치아 마모율과 관련되어 있다. ${ }^{41}$

$\mathrm{Molnar}^{42}$ 는 농경 시대 집단보다 북미 원주민의 수렵-채 집 시대 집단에서 더 심한 마모가 나타난다고 하였다. 그 는 이것을 수렵-채집 인들의 음식이 훨씬 다양하였다는 것과 식재료 가공법에 기인한다. 질기고 섬유질이 많은 음식은 지속적이고 센 저작을 요구하는데 따라서 광범위 한 측방 저작운동이 필요하고 이것은 비교적 편평한 교 합면을 만들게 된다. 정제된 음식은 저작을 많이 할 필요 가 없고 결과적으로 경사가 심한 마모된 교합면을 만들 게 된다. Smith ${ }^{43}$ 는 수렵-채집 인들이 농경사회 사람들보 다 저작의 과정이 더 많이 필요하였기 때문에 더 편평한 구치부 교합면을 갖는다고 하였다. 중국 양샤오 지역의 신석기 시대 유골 연구에 의하면 전치부와 구치부 사이에 서 마모도의 차이가 많았다. ${ }^{44}$ 이것은 수렵-채집 인들이 전치를 사용하여 음식을 끊어내고 딱딱한 과일을 벗겨내 
고 또는 전치를 여타의 연장처럼 사용하기도 한다는 것 을 의미한다.

Boldsen ${ }^{45}$ 이 북부 덴마크의 유골들을 대상으로 한 연 구에 의하면 1300년 이후부터 치아 마모가 급격하게 증 가함이 관찰되었다. 1300 년 전에는 인구가 점진적으로 서서히 증가하여 많은 농촌 마을 사회가 형성되었고 13 세기말에 이르러 인구는 최대치에 도달하였다. 하지만 1320년대와 30년대에 대부분의 북부 유럽은 여러 해 동 안 연속적인 기근을 경험하게 된다. 또한 14 세기 중반에 흑사병으로 많은 인구가 사라졌다. 그는 14세기 전반부 의 북부 유럽의 생활여건 악화로 인해 이 시기의 유골에 서 치아 마모가 높아졌다고 하였다.

식습관과 식재료 가공법은 고고학적 인구 집단의 치아 마모도와 그 양상을 논의할 때 주된 요인으로 언급된다. 식재료 가공법 특히 곡물의 표면을 처리하는 과정에서 맷돌의 사용은 어느 시대이든 보편적으로 있었지만 그 재료는 지역에 따라 많은 차이가 난다. 중동의 북부에서 는 현무암을 대부분 사용하였지만 남부에서는 사암이나 석회암을 더 많이 사용하였다. 후자는 더 마모성이 높은 암석으로 중동의 남부인들이 북부인들 보다 마모도가 더 높은 것과 관련있다. ${ }^{46}$ 중동의 사막 인근 지역에서는 대구 치의 마모도가 더 높게 나타나는 데 이것은 사막에서 날 라온 먼지가 공기중과 음식에 많았다는 것과 관련있다.

중세는 음식이 부족한 시기였기 때문에 빈부 격차가 증폭되어 나타났던 시기였다. 이 시기의 의사들이 권고사 항으로 농부들이 더 많은 채소와 빵을 먹을 필요가 있다 고 평가한 문서가 존재한다. ${ }^{47}$ 채소와 빵은 부자들이 주 로 먹는 고기보다 훨씬 거칠었다. 농부들이 먹는 음식의 거친 정도는 맷돌에서 떨어져 나온 광물질과 식물석 또 는 질긴 식물들이 많은 음식들 같은 많은 요소들에 의해 결정된다. 불완전하게 세척된 줄기, 뿌리와 채소는 높은 치아 마모와 관련되어 있다. ${ }^{45,47}$ Aubry 등 ${ }^{48}$ 은 남성 농부 의 치아가 수녀보다 더 마모가 되었는데 그 이유는 수녀 들은 밀빵을 먹었는데 반해 농부들은 더 거친 보리빵을 먹었다는 점으로 설명하였다. 또한, 중세시대의 치아 마 모는 관련된 지역에 따라 다양하게 나타난다. 프랑스의 체빌리-라루 지역의 유골발굴조사에서 매우 마모된 치아 들은 단지 $20 \%$ 에 불과하였다. Hadjouis ${ }^{49}$ 는 이런 비교적 양호한 구강 환경은 유제품과 고기를 많이 먹는 식습관 과 양호한 맷돌 상태에서 기인한다고 하였다.

중세시대 이후부터 사회적 범주와 지리학적 특성에 따 라 치아 마모는 전진적으로 감소하게 된다. 이런 변화는
밀가루 입자가 점점 더 작아지고 균질화 되는 것과 관련 이 있다. $\operatorname{Kerr}^{50}$ 는 영국 중세 인구의 심한 치아 마모의 주 된 이유가 식량 산업 때문이라고 주장하였다. 가금류(칠 면조, 거위, 그리고 비둘기) 고기는 식생활의 많은 부분을 차지하였고 중세 영국인들은 골수를 음미하기 위해 작은 뼈들은 으깨서 먹기를 좋아했다고 한다. 이런 식습관이 높은 치아 마모와 관련이 있다.

중세시대에는 치아 마모가 기원 전 시대의 농부들과 비교하여 비슷하였지만 Kaifu 등 ${ }^{51}$ 에 의하면 대구치의 마 모는 중세시대를 지나고 바로 감소하기 시작한다. 대구 치 마모의 감소는 조리기법의 발전과 식재료 가공의 변 화 특히 포크의 일반화에 기인한다고 하였다. 프랑스에 서는 포크가 1574년 궁중에서 처음 등장하였고 익힌 배 를 먹을 때만 사용하였다고 한다. 17 세기 초반에 들어서 야 비로서 포크가 보편화 되었다. 이전의 농부들은 음식 을 주로 손으로 먹었고 주로 앞니를 사용했으나 포크의 사용으로 음식을 구강의 뒤쪽으로 넣는 것을 가능하게 되어 전치부의 마모가 감소하였다. ${ }^{47}$

최근 들어 한국에서도 치아를 이용한 고고학적 연구 들이 간간히 발표되고 있지만 그 양은 아직 미미한 수준 이라고 할 수 있다. 2008년 창녕 송현동의 고대 가야의 유적지에서 1500 년 전의 사람 유골이 발견되었다. 이 유 골의 연령 감정을 하기 위해 치아 마모도를 측정하여 현 대 한국인의 수치와 비교하였다. ${ }^{52}$ 그 결과 추정된 나이 는 타케이의 방법으로는 $39.05 \pm 5.00$, 윤의 방법에 의하 면 $42.38 \pm 4.97$ 로 계산 되었다. 하지만 추가적으로 방사 선 촬영을 한 결과 불완전하게 형성된 하악 제 3 대구치가 발견되었다. 하악 제 2 대구치와 제 3 대구치의 형성 정도를 이용한 측정법에 따르면 유골은 약 $16.44 \pm 1.27$ 세 정도 였던 것으로 추정되었다. 결론적으로 이 유골의 주인은 10 대 후반의 여성인 것으로 최종 판정되었다. 이 사례에 서 보다시피 현대인과 고대인의 마모도에는 많은 차이가 존재한다.

2009년 경기도 고양에서 출토된 유골을 조사한 결과 유골은 조선 후기의 것으로 판정되었다. 이를 Moon은 50 년대 한국 전쟁 시 집단 희생된 민간인 유골과 비교하 였다. ${ }^{53}$ 그 결과 모든 치아에서 조선 후기 집단의 마모도 가 현대 집단보다 훨씬 높았다. 조선 후기의 식재료에서 채소류 $(34.3 \%)$ 가 차지하는 비율이 가장 높았으며 다음 으로 잡곡류(22.5\%)와 육류(10.8\%)였다. ${ }^{54}$ 채소와 같이 식이섬유가 많은 음식이 특히 치아의 마모를 심하게 하 기 때문에 조선 후기 사람들의 채식 위주의 식생활이 치 
아 마모에 영향을 준 것으로 보인다.

현재까지 고고학적으로 치아 마모의 의미를 다양하게 해석한 연구들이 많이 이루어졌다. 하지만 너무 특정한 집단들에 대해서 병렬식의 연구가 이루어졌기 때문에 커 다란 흐름으로 정리되기에는 아직 부족한 점이 많이 있 다. 또한 아직 해석에 초점이 맞춰져 있어서 그 마모가 이 루어지는 근본적인 발단에 대한 연구가 결여된 상태이 다. 근본적으로 어떻게 치아 마모가 생기는 지에 대한 것 이 밝혀지면 그 해석의 여지가 훨씬 넓어질 것이다.

\section{부정교합에서 치아 마모의 의미}

교합면과 인접면에서 치아 마모가 크게 일어나는 것은 여러 포유류에서 공통적으로 일어나는 현상이다. ${ }^{51}$ 중세 시대의 하악골을 관찰하면 치아 과밀(crowding)의 빈도 가 매우 낮다. 제 3 대구치는 대부분 존재하였고 치아-턱 의 부조화는 드물었다. ${ }^{47} \mathrm{Begg}^{55}$ 는 마모된 치열궁에서는 치아의 과밀이 나타나지 않는다고 하였고 많은 부정교합 이 치아 마모가 충분히 심하지 않아서 나타난다고 하였 다. 그는 ‘교모성 교합’을 “해부학적으로 그리고 기능적 으로 올바른 교합’이라고 주장했고 “교과서적인 교모가 없는 일반 교합”을 틀린 개념이라고 보았다. 그는 마모 가 줄어들면서 그로 인해 '교모성 교합’의 발달하지 못한 것이 현대 사회에서 여러 치아 문제가 증가하는 주된 원 인이라고 하였다.

광범위한 인접면 마모와 치열궁 길이의 감소는 화석과 현재의 유인원에게서 관찰된다. ${ }^{56}$ 하지만 인접면의 빈 공 간은 관찰되지는 않다. 이런 점은 근심이동(mesial drift) 의 증거로 여겨진다. 전치가 마모되면서 설측으로 기우는 과정은 전방 치열궁의 빈 공간을 닫는 역할을 한다. 현대 인의 구치부 치아의 근심이동은 종적 cephalometric 연 구에서 관찰된다. ${ }^{51}$ 근심이동의 구동력은 논란거리이지 만 인접치와 연결된 transeptal fiber 체계의 견인이 이런 과정의 중요 역할을 한다는 상당한 실험적 증거가 존재 한다. ${ }^{57}$

그러나, $\mathrm{Begg}$ 의 주장은 여러 연구자들에게 반박되었 다. 그들은 환경요소의 변화(모유수유의 감소, 저작 기능 의 약화, 구호흡의 증가)가 상악골의 발달을 막는다고 하 였다. ${ }^{58,59}$ Rando 등 ${ }^{60}$ 은 중세 유골에서 두개골과 하악골 이 전반적으로 현대의 것보다 크고 치열궁도 더 넓다고 하였다. 영양상태가 나아졌고 신생아 시기 환경의 개선 으로 현대 치아의 치관은 중세 시대의 것보다 더 크다. ${ }^{61}$
따라서, 그는 현대인은 기저골이 더 작고 치아가 더 크기 때문에 문제가 생겼다고 주장하엿다. 하지만 치아 마모 가 감소하면서 제 3 대구치의 매복이 증가하였다고 주장 하는 연구들도 꾸준히 보고되었다. ${ }^{62,63}$

치아 과밀과 제 3 대구치의 매복의 빈도 또는 결손의 빈 도가 높아지는 것은 부드러운 음식을 먹는 것과 관련이 있을 수 있다. 여러 학자들이 이런 주장을 하고 있다. 하 지만 다른 이들은 부정교합의 원인이 되는 공간의 부족 은 교합력이 줄어들면서 악궁의 기저골이 작아졌기 때문 이라고 하였다. 그들은 마모가 없어서 커진 치아가 큰 영 향을 주지는 않는다고 보았다. ${ }^{47}$

$\mathrm{Begg}$ 의 주장대로 현대 성인의 Scissor occlusion과 interlocking 교두 관계는 청소년기의 지속이라고 볼 수 있 고 이것은 원래의 우리 몸의 디자인을 고려할 때 예상치 못한 상황이라고 할 수 있다. 그러나 ‘교모성 교합’은 과 거의 심한 마모 환경에서 타협하며 생겨난 결과물로 보 는 것이 타당할 것이다. 지난 천 년간 치아 마모의 급격한 감소로 원래의 치열의 디자인과 현재 환경 사이의 불일치 가 생겨났을 수 있다. 그러므로 치아 마모의 감소 효과는 철저히 검증되어야 할 필요가 있다. 비록 치아 마모의 감 소가 여러 가지 방식으로 치열에 영향을 미쳤겠지만 최 근 들어 심하게 배열이 잘못된 치열이 증가하는 것은 다 른 요소들, 즉 저작 습관의 변화와 턱뼈의 발달이 충분치 않은 것과 관련 있을 것으로 보인다. ${ }^{51}$

현대에 와서 부정교합은 갈수록 증가하는 것은 부정할 수 없는 현실로 보인다. Lindsten 등 $^{64}$ 은 60 년대생 어린 이와 비교하였을 때 80 년대생 어린이들에게서 부정교합 이 더 많이 나타난다고 하였다. Marinelli 등 ${ }^{65}$ 은 이탈리아 의 50 년대 생 혼합 치열기 어린이의 자료를 90 년대생 어 린이의 자료와 비교하였을 때 90 년대생 어린이들이 훨씬 높은 유구치 마모도를 보였고 부정교합도 높게 나타났 다고 하였다.

알레르기의 빈도가 높아지면서 구호흡이 증가된 것도 부정교합의 증가와 관련이 있다. 실제로 50 년대 아이들 에서 구호흡의 비율은 3\% 였지만 90 년대 아이들에게서 는 $21 \%$ 로 높게 나타났다. ${ }^{65}$ 또한, 1530 명의 미국인을 대 상으로 한 연구에 의하면 전치부 개방교합을 가진 어린 이가 그렇지 않은 어린이 보다 마모 정도가 낮았다. ${ }^{66}$ 이 부분들도 앞으로 많이 연구가 이루어져야 할 것이다. 


\section{결론}

치아 마모는 중세에서 현대로 넘어오면서 급격히 감소 하였지만 최근 들어 다시 증가하고 있다는 보고들이 있 다. 이는 현대의 스트레스 높은 도시적 환경과 관련이 있 을 것으로 보인다. 하지만 상관관계는 더 많은 연구들로 입증이 되어야 한다. 치아 마모를 결정하는 여러 가지 다 양한 요소들이 존재하기 때문에 일반적인 기준으로 치아 마모를 이용해서 연령감정을 하는 것은 아직 많은 논란 거리이다. 고고학적으로 많은 치아 마모 연구가 이루어 져 왔지만 다분히 지엽적인 연구에 한정되어서 전체적인 맥락을 도출하기에는 아직 많은 연구가 필요한 상태이 다.

많은 연구들에서 치아 마모를 가지고 해석을 하려고 하지만 그 해석의 폭이 아직은 좁은 상태이다. 근본적으 로 치아 마모가 어떻게 어떤 식으로 발생하는 지에 대한 좀 더 구체적인 연구들이 더 많이 진행이 된다면 치아 마 모의 의미를 더 잘 해석할 수 있을 것이다. 그렇게 된다면 고고학적인 영역 뿐만 아니라 치과 임상적으로도 활용할 수 있을 것이다. 또한 치아 마모의 변화와 현대인에게서 의 부정교합의 증가의 관계를 추론하는 것에도 많은 도 움이 될 것이다.

\section{Acknowledgements}

이 논문은 2018년도 원광대학교의 지원에 의해 수행되 었음.

\section{ORCID}

Soo-Jeong Hwang https://orcid.org/0000-0003-47251512

Min-Seock Seo https://orcid.org/0000-0001-7203-7775

\section{References}

1. Kidd EA, Smith BG. Tooth wear histories: a sensitive issue. Dent Update 1993;20:174-8.

2. Smith BG, Knight JK. A comparison of patterns of tooth wear with aetiological factors. Br Dent J 1984;157:16-9.

3. Bartlett D, Phillips K, Smith B. A difference in perspective-the north American and European interpretations of tooth wear. Int J Prosthodont 1999;12:401-8.

4. Ganss C. Definition of erosion and links to tooth wear. Monogr Oral Sci 2006;20:9-16.

5. Lussi A, Carvalho TS. Erosive tooth wear: a multifactorial condition of growing concern and increasing knowledge. Monogr Oral Sci 2014;25:1-15.

6. Johansson AK, Omar R, Carlsson GE, Johansson A. Dental erosion and its growing importance in clinical practice: from past to present. Int J Dent 2012;2012:632907.

7. Jaeggi T, Lussi A. Prevalence, incidence and distribution of erosion. Monogr Oral Sci 2014;25:55-73.

8. Davies TGH, Pedersen PO. The degree of attrition of the deciduous teeth and first permanent molars of primitive and urbanized Greenland natives. $\mathrm{Br}$ Dent J 1955;99:35-43.

9. Moyers RE. Handbook of orthodontics. 4th ed. Chicago; Year Book Medical Publishers; 1988.

10. Shaw JCM. The teeth, the bony palate and the mandible in the Bantu races of South Africa. London; Bale, Sons and Danielson; 1931.

11. Kontaxopoulou I, Alam S. Risk assessment for tooth wear. Prim Dent J 2015;4:25-9.

12. Wetselaar P, Vermaire JH, Visscher CM, Lobbezoo F, Schuller AA. The prevalence of tooth wear in the Dutch adult population. Caries Res 2016;50:543-50.

13. Hugoson A, Bergendal T, Ekfeldt A, Helkimo M. Prevalence and severity of incisal and occlusal tooth wear in an adult Swedish population. Acta Odontol Scand 1988;46:255-65.

14. Van't Spijker A, Rodriguez JM, Kreulen CM, Bronkhorst EM, Bartlett DW, Creugers NH. Prevalence of tooth wear in adults. Int J Prosthodont 2009;22:35-42.

15. Wei Z, Du Y, Zhang J, Tai B, Du M, Jiang H. Prevalence and indicators of tooth wear among Chinese adults. PLoS One 2016;11:e0162181.

16. Manfredini D, Restrepo C, Diaz-Serrano K, Winocur E, Lobbezoo F. Prevalence of sleep bruxism in children: a systematic review of the literature. J Oral Rehabil 2013;40:631-42.

17. De Luca Canto G, Singh V, Bigal ME, Major PW, Flores-Mir C. Association between tension-type headache and migraine with sleep bruxism: a sys- 
tematic review. Headache 2014;54:1460-9.

18. Soares LG, Costa IR, Brum Júnior JDS, Cerqueira WSB, Oliveira ES, Douglas de Oliveira DW, Gonçalves PF, Glória JCR, Tavano KTA, Flecha OD. Prevalence of bruxism in undergraduate students. Cranio 2017;35:298-303.

19. Brignardello-Petersen R. Severe tooth wear has a negative psychological impact, but it is not related to overall oral health-related quality of life. J Am Dent Assoc 2017;148:e52.

20. Ohayon MM, Li KK, Guilleminault C. Risk factors for sleep bruxism in the general population. Chest 2001;119:53-61.

21. Ahlberg J, Rantala M, Savolainen A, Suvinen T, Nissinen M, Sarna S, Lindholm H, Könönen M. Reported bruxism and stress experience. Community Dent Oral Epidemiol 2002;30:405-8.

22. Nakata A, Takahashi M, Ikeda T, Hojou M, Araki S. Perceived psychosocial job stress and sleep bruxism among male and female workers. Community Dent Oral Epidemiol 2008;36:201-9.

23. Al-Omiri MK, Lamey PJ, Clifford T. Impact of tooth wear on daily living. Int J Prosthodont 2006; 19:601-5.

24. Ray DS, Wiemann AH, Patel PB, Ding X, Kryscio RJ, Miller CS. Estimation of the rate of tooth wear in permanent incisors: a cross-sectional digital radiographic study. J Oral Rehabil 2015;42:460-6.

25. Willems G. A review of the most commonly used dental age estimation techniques. J Forensic Odontostomatol 2001;19:9-17.

26. Vieira EP, Barbosa MS, Quintão CC, Normando D. Relationship of tooth wear to chronological age among indigenous Amazon population. PLoS One 2015;10:e0116138.

27. Kim YK, Kho HS, Lee KH. Age estimation by occlusal tooth wear. J Forensic Sci 2000;45:303-9.

28. Yun JI, Lee JY, Chung JW, Kho HS, Kim YK. Age estimation of Korean adults by occlusal tooth wear. J Forensic Sci 2007;52:678-83.

29. Faillace KE, Bethard JD, Marks MK. The applicability of dental wear in age estimation for a modern American population. Am J Phys Anthropol 2017; 164:776-87.

30. Al-Dlaigan YH, Shaw L, Smith A. Dental erosion in a group of British 14-year-old school children. Part I: prevalence and influence of differing socioeconomic backgrounds. Br Dent J 2001;190:145-9.

31. Millward A, Shaw L, Smith A. Dental erosion in four-year-old children from differing socioeconomic backgrounds. ASDC J Dent Child 1994;61:263-6.

32. Waldron HA. Are plague pits of particular use to palaeoepidemiologists? Int J Epidemiol 2001;30: 104-8.

33. Caglar E, Kuscu OO, Sandalli N, Ari I. Prevalence of dental caries and tooth wear in a Byzantine population (13th c. A.D.) from northwest Turkey. Arch Oral Biol 2007;52:1136-45.

34. Karme A, Rannikko J, Kallonen A, Clauss M, Fortelius M. Mechanical modelling of tooth wear. J R Soc Interface 2016;13:20160399.

35. Masotti S, Bogdanic N, Arnaud J, Cervellati F, Gualdi-Russo E. Tooth wear pattern analysis in a sample of Italian Early Bronze Age population. Proposal of a 3-D sampling sequence. Arch Oral Biol 2017;74:37-45.

36. Brabant H. Evaluation of 20 years' experience in scientific dental research. Rev Belge Med Dent 1973;28:179-86.

37. Esclassan R, Grimoud AM, Ruas MP, Donat R, Sevin A, Astie F, Lucas S, Ubezy E. Dental caries, tooth wear and diet in an adult medieval (12th-14th century) population from mediterranean France. Arch Oral Biol 2009;54:287-97.

38. Slaus M, Pećina-Hrncević A, Jakovljević G. Dental disease in the late medieval population of Nova Raca, Croatia. Coll Anthropol 1997;21:561-72.

39. Masotti S, Bogdanic N, Arnaud J, Cervellati F, GualdiRusso E. Tooth wear pattern analysis in a sample of Italian Early Bronze Age population. Proposal of a 3-D sampling sequence. Arch Oral Biol 2017;74:37-45.

40. Anderson JE. Human skeleton of Tehuacan. Science 1965;148:496-7.

41. Elvery MW, Savage NW, Wood WB. Radiographic study of the broadbeach aboriginal dentition. Am J Phys Anthropol 1998;107:211-9.

42. Molnar S. Human tooth wear, tooth function, and cultural variability. Am J Phys Anthropol 1971;34: 175-89.

43. Smith BH. Patterns of molar wear in hunter-gath- 
erer and agriculturalists. Am J Phys Anthropol 1984;63:39-56.

44. Meng Y, Zhang HQ, Pan F, He ZD, Shao JL, Ding Y. Prevalence of dental caries and tooth wear in a Neolithic population (6700-5600 years BP) from northern China. Arch Oral Biol 2011;56:1424-35.

45. Boldsen JL. Analysis of dental attrition and mortality in the Medieval village of tirup, Denmark. Am J Phys Anthropol 2005;126:169-76.

46. Chattah NL, Smith P. Variation in occlusal dental wear of two Chalcolithic populations in the southern Levant. Am J Phys Anthropol 2006;130:471-9.

47. Esclassan R, Hadjouis D, Donat R, Passarrius O, Maret D, Vaysse F, Crubézy E. A panorama of tooth wear during the medieval period. Anthropol Anz 2015;72:185-99.

48. Aubry M, Mafart BY, Bouville CP; Université d'Aix-Marseille II (1969-2011). Etude paléoodontologique de populations préhistoriques et historiques de Provence: l'hypogée chalcolithique de Roaix (Vaucluse) et le cimetiére médiéval de SaintPierre de l'Almanarre (Var). PhD Thesis; Université de la Méditerranée; 2003. p. 1-262.

49. Hadjouis D. Les populations médiévales du Valde-Marne: Dysharmonies cranio-faciales, maladies bucco-dentaires et anomalies du développement dentaire au cours du Moyen Age. Paris; Artcom; 1999. p. 1-173.

50. Kerr NW. Dental pain and suffering prior to the advent of modern dentistry. Br Dent J 1998;184:397-9.

51. Kaifu Y, Kasai K, Townsend GC, Richards LC. Tooth wear and the "design" of the human dentition: a perspective from evolutionary medicine. Am J Phys Anthropol 2003;37:47-61.

52. Lee S, Lee UY, Han SH, Lee SS. Forensic odontological examination of a 1500 year-old human remain in ancient Korea (Gaya). J Forensic Odontostomatol 2011;29:8-13.

53. Moon H. Dental pathology of human bone remains from northern Gyeonggi region in the late Joseon dynasty. Master's thesis; Department of Archeology, Chungbuk National University; 2013.

54. Bok HJ. The literary investigation on types and cooking method of Bap (boiled rice) during Joseon dynasty (1400's-1900's). J Korean Soc Food Culture
2007;22:721-41.

55. Begg PR. Stone age man's dentition with reference to anatomically correct occlusion, the etiology of malocclusion and a technique for its treatment. Am J Orthodont 1954;40:517-31.

56. Wolpoff MH. Interstitial wear. Am J Phys Anthropol 1971;34:205-27.

57. Roux D, Chambas C, Normand B, Woda A. Analysis of tooth movement into an extraction space in the rat. Arch Oral Biol 1990;35:17-22.

58. Corrucini RS. Australian aboriginal tooth succession, interproximal attrition and Begg's theory. Am J Orthod Dentofacial Orthop 1990;97:349-57.

59. Proffit WR, Fields HW. Contemporary orthodontics. 2nd ed. St. Louis; Mosby Year Book; 1993.

60. Rando C, Hillson S, Antoine D. Changes in mandibular dimensions during the mediaeval to postmediaeval transition in London: a possible response to decreased masticatory load. Arch Oral Biol 2014; 59:73-81.

61. Lindsten R, Ogaard B, Larsson E. Dental arch space and permanent tooth size in the mixed dentition of a skeletal sample from the 14th to the 19th centuries and 3 contemporary samples. Am J Orthod Dentofacial Orthop 2002;122:48-58.

62. Rajasuo A, Murtomaa H, Meuman JH. Comparison of the clinical status of third molars in young men in 1949 and 1990. Oral Surg Oral Med Oral Pathol 1993;76:694-8.

63. Beeman CS. Third molar management: a case for routine removal in adolescent and young adult orthodontic patients. J Oral Maxillofac Surg 1999;57:824-30.

64. Lindsten R, Ogaard B, Larsson E. Transversal dental arch dimensions in 9-year-old children born in 1960s and the 1980s. Am J Orthod Dentofacial Orthop 2001;120:576-84.

65. Marinelli A, Alarashi M, Defraia E, Antonini A, Tollaro I. Tooth wear in the mixed dentition: a comparative study between children born in the 1950s and the 1990s. Angle Orthod 2005;75:340-3.

66. Cunha-Cruz J, Pashova H, Packard JD, Zhou L, Hilton TJ; for Northwest PRECEDENT. Tooth wear: prevalence and associated factors in general practice patients. Community Dent Oral Epidemiol 2010;38:228-34. 


\section{치아 마모의 해석-논문 고찰}

\section{황수정', 서민석 ${ }^{2 *}$}

${ }^{1}$ 건양대학교 치위생과

${ }^{2}$ 원광대학교 대전치과병원 치과보존과

치아 마모로 인해 치아 경조직은 없어지게 된다. 이것은 여러 가지 변수가 작용하는 과정이다. 오랜 시간 동안 치아 마모 는 일상적인 임상 영역에서는 별다른 과심을 받지 못하였지만 최근 들어 관심이 점점 더 커지고 있다. 인간의 평균 수명 이 계속 늘어가면서 치아의 중요도가 더 증가하기도 하였고 구강 위생이 보편화되고 치과 치료가 발전하면서 치아가 더 욱 오랜 동안 구강 내에서 유지되고 있기 때문에 치아 마모가 더 많은 관심을 불러 일으키고 있는 것이다. 치아 마모는 자 연적으로 한방향성을 가지고 있기 때문에 이를 통해 개개인의 연령 감정을 하는데 자주 이용되었다. 당연하게도 치아 마 모를 이용한 연령감정은 상대적으로 넓은 범주에서 이루어지고 그 정확성도 의심받고 있다. 고대에서 중세시대까지 치아 마모는 아주 심하게 있어왔다. 그래서 치아 마모는 매우 많은 지역에서 연구되어 왔다. 하지만 아직 이런 개개의 연구들 이 통합적인 의미 도출로 이어지지는 못하고 있다. 따라서 지금까지의 연구들을 토대로 통합적인 치아 마모의 이해를 위 한 세부적인 연구와 접근이 필요한 시점이다.

(구강회복응용과학지 2018;34(3): 137-46)

주요어: 교모; 연령 감정; 치아 마모; 치아 부식 